\title{
Water, vapour and heat transport in concrete cells for storing radioactive waste
}

\author{
M. Carme Chaparro ${ }^{\mathrm{a}, \mathrm{b}, \mathrm{c}, *}$, Maarten W. Saaltink $\mathrm{k}^{\mathrm{a}, \mathrm{c}}$ \\ ${ }^{a}$ Department of Civil and Environmental Engineering, Universitat Politècnica de \\ Catalunya (UPC), Jordi Girona 1-3, 08034 Barcelona, Spain \\ ${ }^{b}$ Institute of Environmental Assessment and Water Research (IDAEA), CSIC, Jordi \\ Girona 18, 08034 Barcelona, Spain \\ ${ }^{c}$ Associated Unit: Hydrogeology Group (UPC-CSIC)
}

\begin{abstract}
Water is collected from a drain situated at the centre of a concrete cell that stores radioactive waste at 'El Cabril', which is the low and intermediate level radioactive waste disposal facility of Spain. This indicates flow of water within the cell. 2D numerical models have been made in order to reproduce and understand the processes that take place inside the cell. Temperature and relative humidity measured by sensors in the cells and thermo-hydraulic parameters from laboratory test have been used. Results show that this phenomenon is caused by capillary rise from the phreatic level, evaporation and condensation within the cell produced by temperature gradients caused by seasonal temperature fluctuations outside. At the centre of the cell, flow of gas and convection also play a role. Three remedial actions have been studied that may avoid the leakage of water from the drain.
\end{abstract}

Keywords: Vapour diffusion, Multiphase flow, Concrete, Numerical model

\section{Introduction}

It is known that concrete in constructions and buildings, can be damaged by exposure to variations of temperature and relative humidity and its service

${ }^{*}$ Corresponding author. Present address: c/Jordi Girona 1-3, Universitat Politècnica de Catalunya (UPC), Building D2, Office 004/1, 08034 Barcelona, Spain. Tel.: +34 934011858.

Email address: m.carme.chaparro@upc.edu (M. Carme Chaparro) 
life reduced by processes involving water flow, heat transport, evaporation and condensation. Several studies investigating these processes have been reported. Bažant and Najjar (1972) studied analytically the dependence of the diffusivity on pore humidity, degree of hydration and temperature in concrete. Andrade et al. (1999) studied experimentally the effects of daily and seasonal variations of external temperature and relative humidity on concrete columns. Häupl et al. (1997) studied the interaction between heat transfer, gas and humidity in materials used in construction by means of numerical models. Lü (2002) developed a numerical model to predict the heat transfer and humidity in buildings, which has been tested experimentally. Liu et al. (2004) developed a method to solve condensation problems using numerical models and experimental data.

In soils evaporation is an important process too. Hence, also an extensive amount of literature exists on the coupled transport of water vapour, liquid water and heat in this type of medium (e.g.; Gawin et al. (1995); Grifoll et al. (2005); Bittelli et al. (2008); Sakai et al. (2009); Banimahd and Zand-Parsa (2013); Gran-Esforzado (2015)). The heat transfer in non saturated porous materials under temperature gradients has also been studied analytically by Philip and De Vries (1957). In unsaturated porous media temperature gradients can cause diffusion of vapour with evaporation at the hot and condensation at the cold side. In theory, this process could saturate parts of the cold side. However, to our knowledge, vapour diffusion, due to temperature gradients, through an unsaturated part of the porous medium followed by condensation and water leakage at the edge of a completely saturated part has not been found in porous media, neither in concrete nor in soils.

Our study was motivated by the transport of water and heat in the radioactive waste facility of 'El Cabril', located in the south of Spain, where water is collected inside concrete cells storing the waste. In 'El Cabril' the low and intermediate level activity radioactive waste are stored. Firstly, the waste, which is a solid material, is stored in metal drums. Secondly, it is placed in concrete containers. When the containers are full, they are filled with mortar. Thirdly, the containers are placed in a concrete cell. When the cell is completely full it is sealed with a concrete slab on top. Finally, the outside is painted with a waterproof paint. In the future, when all the cells are full, the whole facility will be protected with a multilayer cover (Gran-Esforzado, 2015).

The first cell was sealed in 1992. From 2003 on, water is collected from a 
drain installed at the centre of each cell indicating flow of water within the cell. This occurred every year in summer and winter. Several hypotheses were suggested to explain this phenomenon. One of them was related to rainwater. However, there is no correlation between rainfall and the periods of the collected water in the drain. Another one was the fact that water could infiltrate into the cell through the junctions of the concrete. However, this hypothesis cannot explain the quantity of collected water. Finally, the hypothesis proposed to explain this phenomenon consists of capillary rise from groundwater, evaporation and condensation within the cell, produced by temperature gradients caused by seasonal temperature fluctuations outside. A sum of several factors contributes to the phenomenon taking place. The aquifer is approximately $3 \mathrm{~m}$ below the base of the cell and is hydraulically connected to the walls of the cell, allowing a capillary rise. The concrete used to build the cells has a low intrinsic permeability and high capacity of retention. So it contains water available for evaporation. A gap of air exists between the wall of the cell and the containers, causing a sufficient temperature difference for vapour diffusion to occur.

A study has been reported where the phenomenon that takes place in 'El Cabril' is explained supported by numerical models (Zuloaga et al., 2006). Nevertheless, it did not take into account the real data of temperature and relative humidity measured in the cells. Moreover, it used thermo-hydraulic parameters from literature instead of parameters of the concrete to build the cells. Furthermore, results were also qualitative because it only considered the roof and one wall of the cell instead of simulating the temperature gradients in the whole cell.

The objective of this work is to study the processes that are taking place inside the cell by means of numerical models. To do so, we take into account the temperature and relative humidity measured by sensors placed inside and outside the cells. Also we used thermo-hydraulic parameters of the concrete used to build the cells. These parameters have been obtained from laboratory tests of the concrete (Villar et al., 2009) and thermo-hydraulic multiphase flow models of evaporation experiments (Chaparro et al., 2015). Moreover, we give some possible scenarios in order to remediable and avoid this problem.

\section{Conceptual model}

Figure 1 displays a scheme of a concrete cell where the radioactive waste is stored, and the conceptual model that explains why water is collected in 
the drain. 'El Cabril' has 28 cells, each one measuring $19.3 \mathrm{~m}$ by $23.8 \mathrm{~m}$ and can storing $1000 \mathrm{~m}^{3}$ of waste. The cells are filled with concrete containers, of $2.20 \mathrm{~m}$ by $2.25 \mathrm{~m}$. Each contains the drums with the radioactive waste. The cells have 4 zones with containers, each zone has 80 containers. The 4 zones are separated with gravel. The wall of the cell and the containers do not fit perfectly. Between them a small gap of air exists. At the base of the containers there is porous concrete underlain by a layer of baytec. Each cell has a drain at its center, which can be accessed through a gallery. This gallery connects all the cells in the platform. The cell is partly buried $(3 \mathrm{~m})$ into the underlying rock. The rest of it is exposed to the atmosphere with its temperature oscillations. The temperature outside the cell oscillates between $40{ }^{\circ} \mathrm{C}$ in summer and $5^{\circ} \mathrm{C}$ in winter. The water table is about $4 \mathrm{~m}$ below the base of the cell.

The conceptual model considers that water can ascend from the phreatic level to the wall of the cell due to capillary rise through the unsaturated rock. In summer, the wall of the cell is hotter and the wall of the container is colder because the air gap acts as a thermal insulation. Thus, water can evaporate from the wall of the cell. Vapour diffuses through the air gap due to the temperature gradient between the wall of the cell and the wall of the container. Water condensates at the wall of the container because of its lower temperature. Consequently, condensed water runs off to the drain. In winter, the wall is colder and the container is hotter. Hence, water evaporates at the container and condenses at the wall. So, again water runs off to the drain. This only occurs in summer and winter because only then the temperature difference across the air gap is large enough to produce this phenomenon.

To understand and quantify these processes it is worthwhile to remember some basic psychrometric properties and relations. The saturated vapour pressure as a function of temperature can be expressed as:

$$
P_{\mathrm{g}, \mathrm{sat}}^{\mathrm{w}}=a \exp \left(\frac{-b}{T}\right)
$$

Where $T$ is the temperature in $\mathrm{K}, a$ and $b$ are parameters which have values of $1.36075 \cdot 10^{11} \mathrm{~Pa}$ and $5.2397 \cdot 10^{3} \mathrm{~K}$, respectively (Olivella et al., 1996a). Suction can be related to the saturated and actual vapour pressure through Kelvin's law.

$$
R H=\frac{P_{\mathrm{g}}^{\mathrm{w}}}{P_{\mathrm{g}, \mathrm{sat}}^{\mathrm{w}}}=\exp \left(\frac{-\psi M^{\mathrm{w}}}{R \rho_{\mathrm{l}} T}\right)
$$




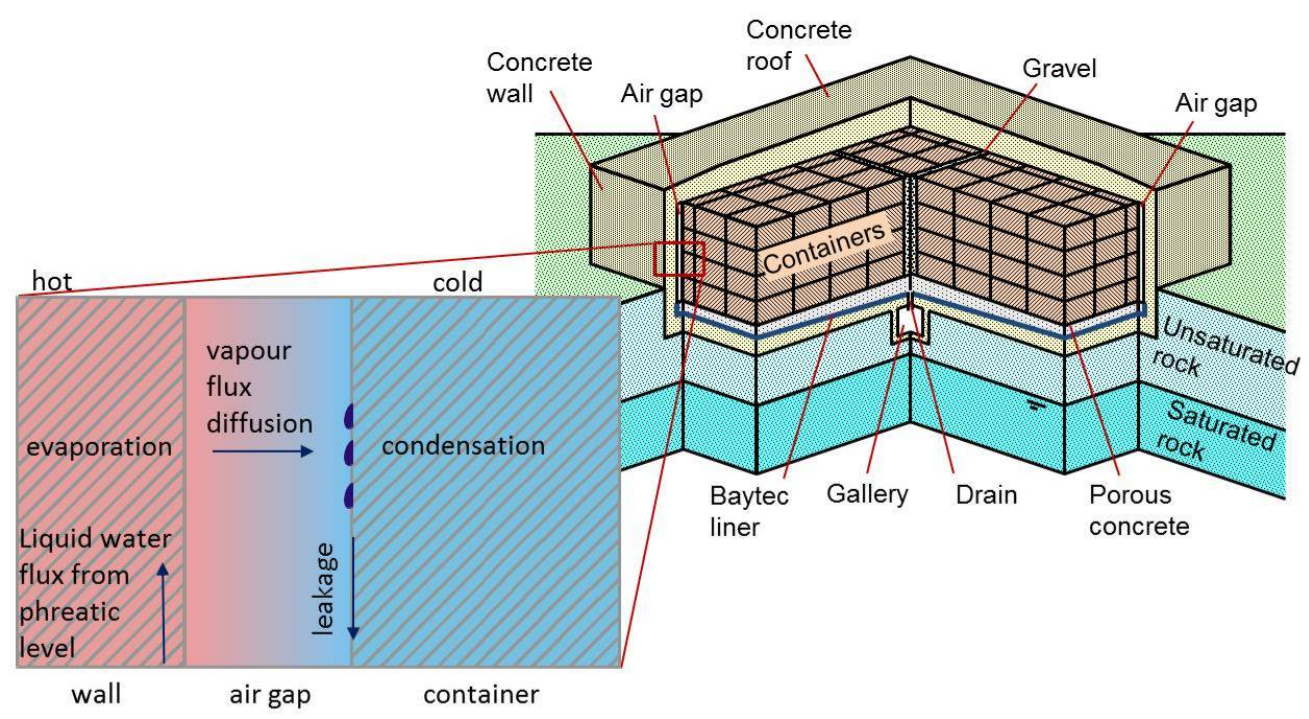

Figure 1: Scheme of a concrete cell and conceptual model. Situation in summer: water ascends from the phreatic surface, evaporates at the hot side (wall of the cell), vapour diffuses through the air gap and water condensates at the cold side (wall of container).

Where $R H$ is relative humidity, $P_{\mathrm{g}}^{\mathrm{w}}$ is the actual vapour pressure, $\psi$ is the suction pressure $\rho_{\mathrm{l}}$ is the density of liquid water $\left(1000 \mathrm{~kg} \mathrm{~m}^{-3}\right), R$ is the gas constant $\left(8.314 \mathrm{~J} \mathrm{~mol}^{-1} \mathrm{~K}^{-1}\right)$ and $M^{\mathrm{w}}$ is the molecular weight of water $\left(0.018 \mathrm{~kg} \mathrm{~mol}^{-1}\right)$. Vapour diffusion can be expressed by means of Fick's law.

$$
i_{\mathrm{g}}^{\mathrm{w}}=\frac{-D M^{\mathrm{w}}}{R T} \nabla P_{\mathrm{g}}^{\mathrm{w}}
$$

Where $i_{\mathrm{g}}^{\mathrm{w}}$ is the flux vapour diffusion $\left(\mathrm{kg} \mathrm{m}^{-2} \mathrm{~s}^{-1}\right)$ and $D$ is the diffusion coefficient $\left(\mathrm{m}^{2} \mathrm{~s}^{-1}\right)$.

Figure 2 shows the classical case of condensation in a cooling volume of air with constant amount of water. Air with a temperature of $30^{\circ} \mathrm{C}$ and relative humidity of $80 \%$ is cooled. As a result the relative humidity increases, maintaining a constant vapour pressure, until it reaches a value of 100\%. At this point (so called dew point) water starts to condensate and vapour pressure drops.

When there is a temperature difference across an air gap, we can look at two extreme cases. The first case considers complete saturation at both ends of the gap $\left(P_{\mathrm{g}}^{\mathrm{w}}=P_{\mathrm{g}, \mathrm{sat}}^{\mathrm{w}}\right.$ and $\left.\psi=0\right)$, that is, both ends are on the line of $100 \%$ relative humidity of figure 2 . Given the temperature difference we can 


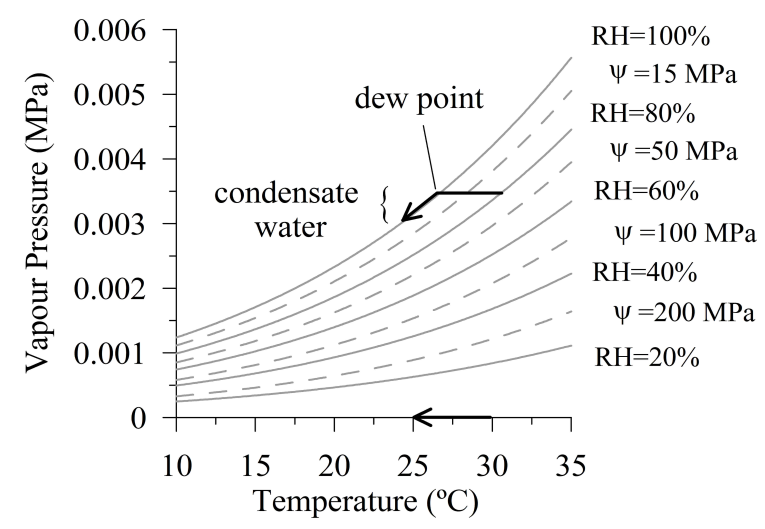

Figure 2: Psychrometric chart. Relation between temperature, vapour pressure, relative humidity and suction. When the temperature of a volume of air decreases, its relative humidity decreases until it reaches the dew point. From then on, if the temperature continues to decrease, water condenses.

calculate the vapour diffusion by substituting equation 2 into 3 :

$$
i_{\mathrm{g}}^{\mathrm{w}}=\frac{-D M^{\mathrm{w}}}{R T} \nabla P_{\mathrm{g}, \mathrm{sat}}^{\mathrm{w}}=\frac{-D M^{\mathrm{w}}}{R T} \frac{d P_{\mathrm{g}, \mathrm{sat}}^{\mathrm{w}}}{d T} \nabla T=\frac{-D M^{\mathrm{w}} b P_{\mathrm{g}, \mathrm{sat}}^{\mathrm{w}}}{R T^{3}} \nabla T
$$

For a temperature of $293.15 \mathrm{~K}\left(20^{\circ} \mathrm{C}\right)$ a diffusion coefficient of $10^{-5} \mathrm{~m}^{2} \mathrm{~s}^{-1}$, an air gap of $0.02 \mathrm{~m}$ and a total gap surface of $800 \mathrm{~m}^{2}$, this would lead to a total diffusive flux of $37 \mathrm{l} \mathrm{d}^{-1}$ for a one degree temperature difference. The second extreme case considers a situation where the cold side is saturated whereas the hot side has dried up to a point where its vapour pressure equals that of the cold side and, consequently, no further diffusion takes place. That is, both sides are on a horizontal line in figure 2 . Then we can calculate the suction at the hot side by substituting equation 1 into 2 .

$$
\psi=\frac{R \rho_{\mathrm{l}} T}{M^{\mathrm{w}}} \ln \left(\frac{P_{\mathrm{g}, \mathrm{sat}}^{\mathrm{w}}(T)}{P_{\mathrm{g}, \mathrm{sat}}^{\mathrm{w}}\left(T_{\mathrm{dew}}\right)}\right)=\frac{R \rho_{\mathrm{l}} b\left(T-T_{\mathrm{dew}}\right)}{M^{\mathrm{w}} T_{\mathrm{dew}}} \Rightarrow \frac{d \psi}{d T}=\frac{R \rho_{\mathrm{l}} b}{M^{\mathrm{w}} T_{\mathrm{dew}}}
$$

For a temperature at the cold side of $293.15 \mathrm{~K}\left(20^{\circ} \mathrm{C}\right)$, a one degree temperature difference could dry the hot side up to a suction of $8.3 \mathrm{MPa}$.

\section{Data from monitored cells}

Two cells were monitored in order to measure the temperature and relative humidity: the first and the last closed cell. The first closed cell was 
the first cell where water was collected in the drain several years after it was closed. Sensors to measure temperature were installed at the walls, at the roof of this cell and another one at the drain. When water started to be collected from the first cell, sensors were installed inside another cell that was still open. For the last closed cell, both, temperature and relative humidity were measured.

\subsection{The first closed cell}

The sensors to measure temperature are thermocouples which have a maximum error of $\pm 0.5^{\circ} \mathrm{C}$. Figure 3 shows the evolution of the daily average temperature outside the cell for the roof and for each wall at $6 \mathrm{~m}$ and at 1 $\mathrm{m}$ from the base of the cell.

The temperature at the roof oscillates more than those at the walls at $6 \mathrm{~m}$ (Figure 3a). Temperatures at the western and southern walls oscillate more than those at the eastern and northern walls, because the last are in the shade of other adjacent cells. The maximum and minimum temperatures are approximately $37^{\circ} \mathrm{C}$ and $5^{\circ} \mathrm{C}$, respectively (Figure 3a). At $1 \mathrm{~m}$ from the base of the cells sensors are below surface (Figure $3 \mathrm{~b}$ ). The sensor at the southern wall has larger oscillation of temperature because this part of the cell had been excavated to inspect potential infiltration through the junctions of the concrete. It is covered by plastic panes, which may create a greenhouse effect. Thus, sensor at the southern wall measure larger temperature oscillation, followed by the west side, east side and north side of the cell. The maximum and minimum temperatures are $33^{\circ} \mathrm{C}$ and $10^{\circ} \mathrm{C}$. As expected, temperatures measured by the sensors at $6 \mathrm{~m}$ and the roof have larger oscillation than those measured at $1 \mathrm{~m}$ because the last ones are below surface. Also a diver was installed in the drain in order to measure the temperature inside the cell (Figure 3b). This was the only place, where the interior could be monitored, because the cell was closed when water started to be collected. Temperature in the cell has little oscillation. It varies between 18.5 and $21.5^{\circ} \mathrm{C}$.

\subsection{The last closed cell}

Vaisala thermo-hygrometers were installed, that measure temperature and relative humidity of a wall of the cell. The error in temperature measurement is $0.25{ }^{\circ} \mathrm{C}$ for temperatures between 10 and $40{ }^{\circ} \mathrm{C}$. For a temperature range between 15 and $25{ }^{\circ} \mathrm{C}$ the error of the relative humidity is $\pm 1 \%$ if the relative humidity is between 0 and $90 \%$, and $\pm 1.7 \%$ if the relative hu-

midity is between 90 and $100 \%$. Also thermocouples were used. However, as 

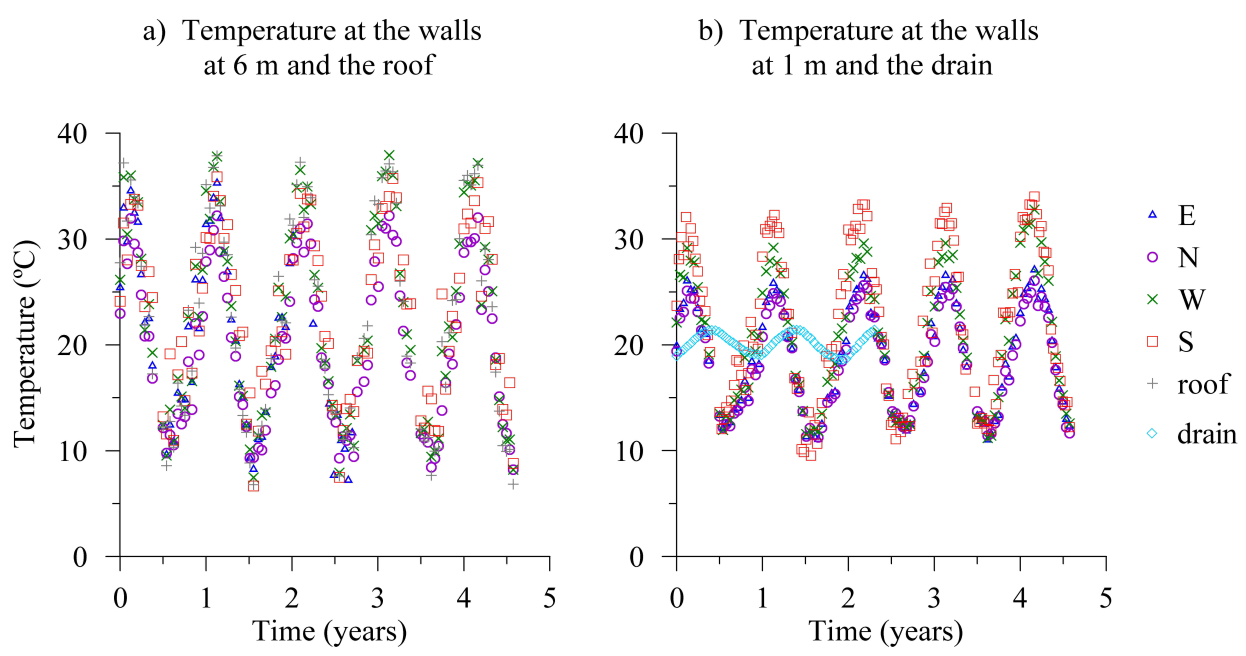

Figure 3: Evolution of the daily average temperature outside the cell at the roof, in the drain and at each wall at $6 \mathrm{~m}$ and at $1 \mathrm{~m}$ above the base of the cell.

they measured practically the same temperatures as the thermo-hygrometers, they will not be discussed further. Figure 4 displays the position of the thermo-hygrometers and the evolution of temperature and relative humidity measured at the wall. One sensor is located at one side of the air gap, on the wall of the cell (HP_07), and another one at the other side of the air gap, on the container (HP_12). Both are situated at $3.5 \mathrm{~m}$ above the base of the cell. Moreover, sensors have been installed at the interface between the containers and the gravel, one of them situated at $1.5 \mathrm{~m}$ and the others situated at $3.5 \mathrm{~m}$ above the base of the cell. Sensors situated at each side of the air gap (HP_07 and HP_12) measured a temperature difference of $2{ }^{\circ} \mathrm{C}$. Sensors measured less temperature oscillation and more retardation, the further away from the wall of the cell (HC_11, HC_08). Sensors at the interior (HC_09, HC_10, HC_11 and HC_08) measured relative humidities that behaved oppositely to the sensors at the air gap (HP_07, HP_12). In winter, when the wall is close to saturation $(\mathrm{RH} \approx 95 \%)$ sensors on the containers are dry $(\mathrm{RH} \approx 60 \%)$. In summer the wall is dry $(\mathrm{RH} \approx 60 \%)$ and sensors on the wall of the container are close to saturation $(\mathrm{RH} \approx 95 \%)$. In general, relative humidity measured by the sensors never reaches $100 \%$. Hence, theoretically not enough water condensates to cause any leakage. We should be careful, however, when interpreting the relative humidity measured by the sensors at the air gap. The sensors are not located inside the concrete, but 
were placed on top of it. As the size of the sensors (about $1 \mathrm{~cm}$ ) is only a bit smaller than the width of the air gap (about $2 \mathrm{~cm}$ ), they measure the relative humidity at some point in the middle of the air gap, which may be similar

for the two sensors. Therefore, the measurements probably do not reflect the situation at the concrete of either the container or the wall. Nevertheless, the temperature measurements by these sensors differ less than that in the concrete because the material used to build the sensors has a large thermal conductivity with respect to that of air. Moreover, these sensors measured temperatures practically identical to those measured by the thermocouples, which are much smaller.

\section{Numerical model}

We first developed a numerical model of the first closed cell, because here water is collected from the drain. We use the temperature measured by the sensors (outside the cell and at the drain), and the leakage rate of condensed water measured at the drain. Afterwards, using the same conceptual model we simulate the last closed cell, where no water is collected, but temperature and relative humidity inside the cell were measured.

\subsection{Balance equations}

These processes have been simulated using CODE_BRIGHT, a finite element computer code that can model multiphase flow and heat transfer (Olivella et al., 1996b). This code solves the balance equations for water (Eq. 6), air (Eq. 7) and energy (Eq. 8). For more details on each equation we refer to Olivella et al. (1994).

$$
\begin{gathered}
\frac{\partial}{\partial t}\left(\theta_{\mathrm{l}} \omega_{\mathrm{l}}^{\mathrm{w}} \rho_{\mathrm{l}}+\theta_{\mathrm{g}} \omega_{\mathrm{g}}^{\mathrm{w}} \rho_{\mathrm{g}}\right)+\nabla \cdot\left(j_{\mathrm{l}}^{\mathrm{w}}+j_{\mathrm{g}}^{\mathrm{w}}\right)=f^{\mathrm{w}} \\
\frac{\partial}{\partial t}\left(\theta_{\mathrm{l}} \omega_{\mathrm{l}}^{\mathrm{a}} \rho_{\mathrm{l}}+\theta_{\mathrm{g}} \omega_{\mathrm{g}}^{\mathrm{a}} \rho_{\mathrm{g}}\right)+\nabla \cdot\left(j_{\mathrm{l}}^{\mathrm{a}}+j_{\mathrm{g}}^{\mathrm{a}}\right)=f^{a} \\
\frac{\partial}{\partial t}\left(E_{\mathrm{s}} \rho_{\mathrm{s}}(1-\phi)+E_{\mathrm{l}} \rho_{\mathrm{l}} S_{\mathrm{l}} \phi+E_{\mathrm{g}} \rho_{\mathrm{g}} S_{\mathrm{g}} \phi\right)+\nabla \cdot\left(i_{\mathrm{c}}+j_{\mathrm{Es}}+j_{\mathrm{El}}+j_{\mathrm{Eg}}\right)=f^{Q}
\end{gathered}
$$

Subscripts refer to phase ( $\mathrm{l}=$ liquid, $\mathrm{g}=$ gas and $\mathrm{s}=$ solid) and superscripts to component $(\mathrm{w}=$ water and $\mathrm{a}=$ dry air $), \theta$ is the volumetric content $(\theta=\phi S)$, $\omega$ is the water or solute mass fraction in liquid or gas phase $\left(\mathrm{kg} \mathrm{kg}^{-1}\right), \rho$ is 

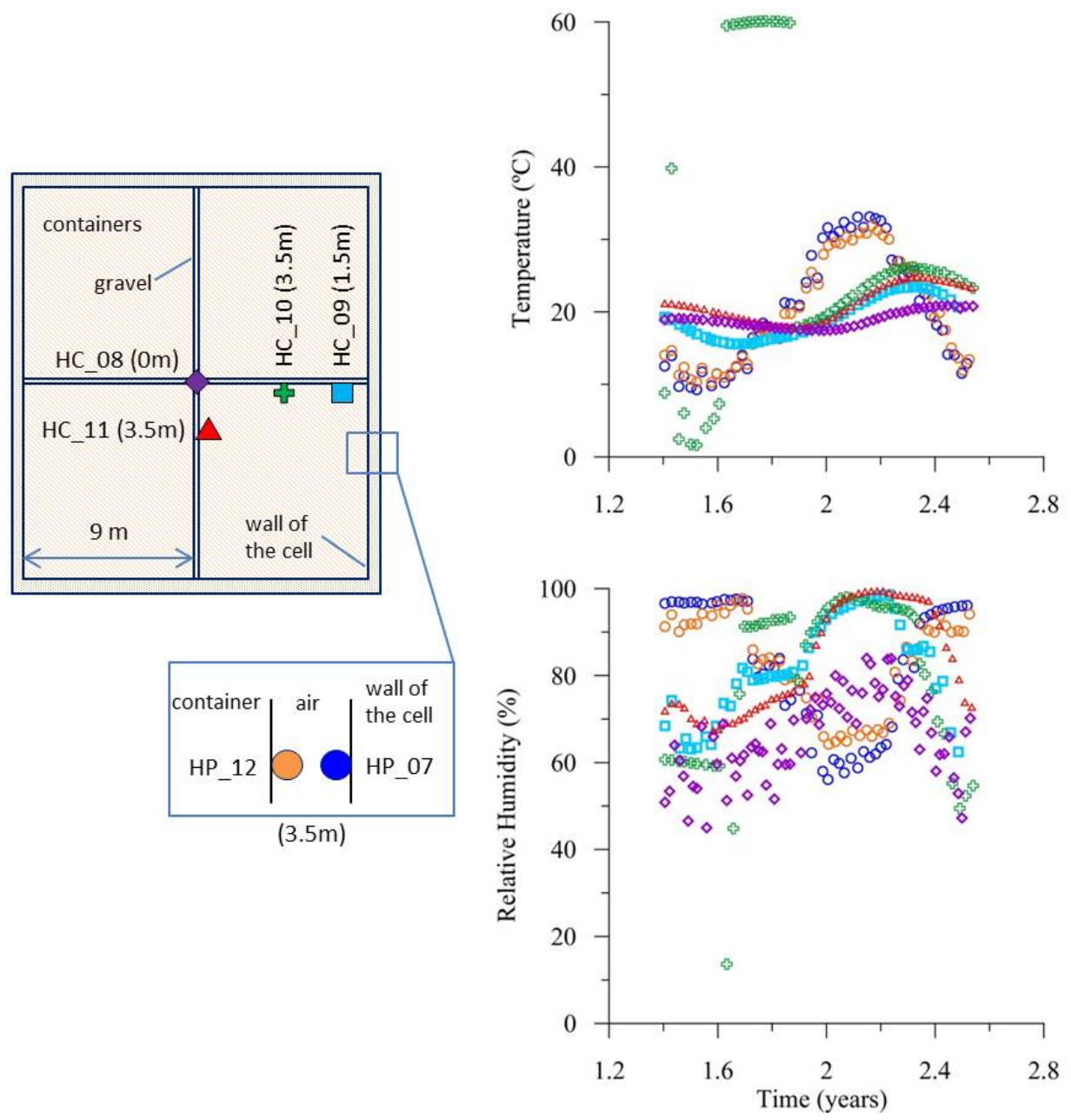

Figure 4: Position of the sensors and evolution of temperature and relative humidity inside the last closed cell. 
the density $\left(\mathrm{kg} \mathrm{m}^{-3}\right), \phi$ is the porosity, $j$ is the mass flux of a component in each phase $\left(\mathrm{kg} \mathrm{s}^{-1} \mathrm{~m}^{-2}\right), E$ is the internal energy per unit of mass for each phase $\left(\mathrm{J} \mathrm{kg}^{-1}\right), S$ is the water saturation and $f$ is the external supply of a component.

Constitutive laws are used to express the parameters of the balance equations as a function of the state variables (liquid pressure, gas pressure and temperature). Thereby, we can take into account important processes and properties such as relative humidity (Eq. 2), Darcy's law for an unsaturated medium, vapour diffusion and heat conduction. Chaparro et al. (2015) give a full list of all constitutive laws used in this model and Olivella et al. (1994) give the details on each equation.

\subsection{Geometry, mesh and materials}

Figure 5 displays the geometry of the numerical model, the mesh and the materials of which the cell is composed. We considered an axisimetric geometry, that is, the geometry of the numerical model is a cylinder, its volume/surface ratio being equal to the real cell. We made 4 axisimetric models, each one representing a quarter of the cell. The model distinguishes between six materials: the concrete of the walls, roof and base of the cell, the containers that store the waste, the air gap between the wall and the containers, the gravel that separates the four zones of containers, the porous concrete underlying the containers and the rock underlying the cell. The mesh consist of 6811 nodes and 6672 quadrilateral elements. It has been refined near the air gap where evaporation and condensation are expected to take place.

\subsection{Thermo-hydraulic parameters}

Some thermo-hydraulic parameters of the concrete (porosity and intrinsic permeability) used in our numerical model were obtained from experimental tests (Villar et al., 2009) and from the calibration of thermo-hydraulic multiphase flow models of evaporation tests (Chaparro et al., 2015). These parameters were used for the concrete of both the cells and the containers. Other parameters (retention curve, relative permeability and thermal conductivity) were calibrated. For the other materials (porous concrete, gravel and rock) we used the same parameters as Massana and Saaltink (2006). Table 1 summarises the parameters used in the numerical model. For further details of all the parameters definitions used in the numerical model, we refer to a previous work of the authors (Chaparro et al., 2015). 


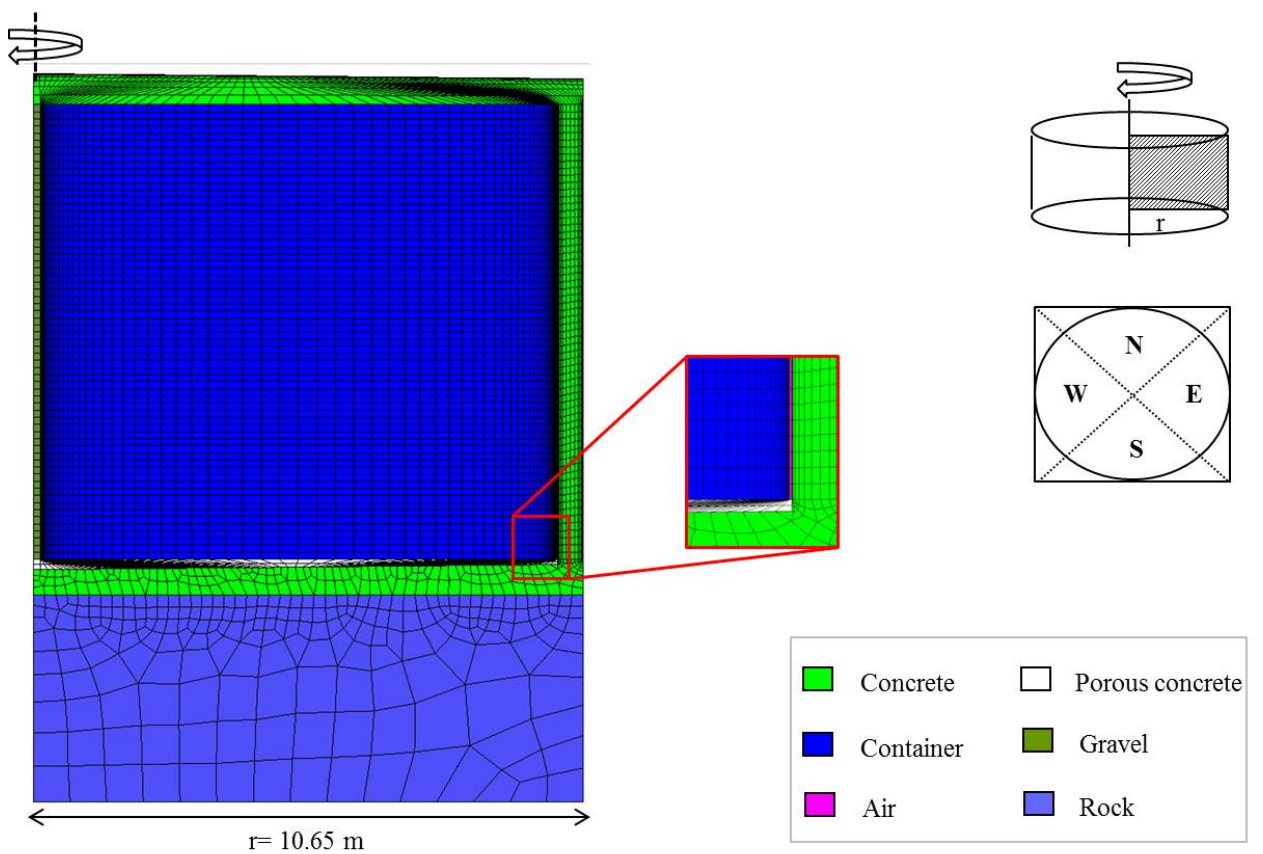

Figure 5: Geometry, mesh and materials of the numerical model

\section{Porosity}

The porosity of the concrete used to build the cells and containers is 0.17 (Villar et al., 2009; Chaparro et al., 2015). The porous concrete has a higher value, 0.3. We used the same porosity for the gravel. The underlying rock has micro fractures filled with clay. So we used a value of 0.2 (Massana and Saaltink, 2006).

\section{Intrinsic permeability}

The intrinsic permeability of the concrete is $1 \times 10^{-18} \mathrm{~m}^{2}$ (Villar et al., 2009; Chaparro et al., 2015). We use the same intrinsic permeability as Chaparro et al. (2015) did, which was tested in thermo-hydraulic multiphase flow models in evaporation tests using the same concrete. Even when the same theoretically composition of the concrete is used, the intrinsic permeability could be different due to structural changes in the concrete during the hardening process. In this model, we fixed the intrinsic permeability of the concrete and we calibrated the retention curve. We used the same value for the cell and containers. For porous concrete, gravel and the rock we used a values of $1 \times 10^{-10}, 1 \times 10^{-11}$ and $1 \times 10^{-15} \mathrm{~m}^{2}$, respectively (Massana and 
Saaltink, 2006).

\section{Retention curve}

We used the van Genuchten model in order to simulate the retention curve:

$$
S_{e}=\left(1+\left(\frac{P_{\mathrm{g}}-P_{1}}{P_{0} \frac{\sigma_{\mathrm{T}}}{\sigma_{0}}}\right)^{\frac{1}{1-m}}\right)^{-m}
$$

where $S_{\mathrm{e}}$ is the effective water saturation, $P_{\mathrm{g}}$ and $P_{1}$ are the gas and liquid pressure respectively $(\mathrm{MPa}), P_{0}$ is the entry pressure $(\mathrm{MPa}), m$ is a shape parameter and $\sigma_{0}$ is the surface tension at $20^{\circ} \mathrm{C}(0.072 \mathrm{~N} / \mathrm{m})$ and $\sigma_{\mathrm{T}}$ is the surface tension at temperature $\mathrm{T}$.

Calibration of the retention curve for concrete to measured leakage rates at the drain resulted in a $P_{0}$ of $3 \mathrm{MPa}$ and a $m$ of 0.34 . Although the value of $m$ is the same as that found by Chaparro et al. (2015), the value of $P_{0}$ is different $(7.7$ versus $3 \mathrm{MPa}$ ). The difference is probably due to hysteresis. Chaparro et al. (2015) determined the retention curve in evaporation tests, where saturation always decreases, whereas in this case saturation increases as well as decreases. The hysteresis had not been taken into account in order to simplify the model; our retention curve represents an average between the drying and wetting retention curves. The temperature oscillations (from $10^{\circ} \mathrm{C}$ in winter to $30^{\circ} \mathrm{C}$ in summer) are taken into account by means of the surface tension $\left(\sigma_{\mathrm{T}}\right)$, which depends on temperature. For porous concrete and gravel we used an entry pressure of $0.0003 \mathrm{MPa}$ and a $m$ of 0.9 . The rock has a $P_{0}$ of $1 \mathrm{MPa}$ and a $m$ of 0.3 (Massana and Saaltink, 2006).

\section{Relative permeability}

The van Genuchten model is used for the relative permeability as a function of saturation.

$$
k_{\mathrm{rl}}=\sqrt{S_{\mathrm{e}}}\left(1-\left(1-S_{\mathrm{e}}^{1 / \mathrm{m}}\right)^{\mathrm{m}}\right)^{2}
$$

where $k_{\mathrm{rl}}$ is the relative permeability of the liquid phase and $m$ is a shape parameter.

We used the van Genuchten model, with $m$ having the same value as that of the retention curve in order to simplify our numerical model. 


\section{Thermal conductivity}

The solid thermal conductivity $\left(\lambda_{\mathrm{s}}\right)$ of the concrete was calibrated. To do this, the model results were fitted to the measured temperature inside the drain. The thermal conductivity of the concrete cell and the concrete containers are different. This is because containers have metal drums inside and the thermal conductivity of metal is larger than that of concrete. The value calibrated is $1.56 \mathrm{~W} \mathrm{~m}^{-1} \mathrm{~K}^{-1}$ for the concrete wall and $3 \mathrm{~W} \mathrm{~m}{ }^{-1} \mathrm{~K}^{-1}$ for the concrete containers. We used a value of $1.5 \mathrm{~W} \mathrm{~m}^{-1} \mathrm{~K}^{-1}$ for the porous concrete and a value of $2.9 \mathrm{~W} \mathrm{~m}^{-1} \mathrm{~K}^{-1}$ for the gravel and the rock (Massana and Saaltink, 2006).

Table 1: Thermo-hydraulic parameters used in the numerical model.

\begin{tabular}{lccccc}
\hline & $\phi$ & $k_{\mathrm{i}}\left(\mathrm{m}^{2}\right)$ & $P_{0}(\mathrm{MPa})$ & $m$ & $\lambda_{\mathrm{s}}\left(\mathrm{W} \mathrm{m}^{-1} \mathrm{~K}^{-1}\right)$ \\
\hline Concrete wall & 0.17 & $1 \times 10^{-18}$ & 3 & 0.34 & 1.56 \\
Concrete container & 0.17 & $1 \times 10^{-18}$ & 3 & 0.34 & 3 \\
Gravel & 0.3 & $1 \times 10^{-11}$ & 0.0003 & 0.9 & 2.9 \\
Porous concrete & 0.3 & $1 \times 10^{-10}$ & 0.0003 & 0.9 & 1.5 \\
Rock & 0.2 & $1 \times 10^{-15}$ & 1 & 0.3 & 2.9 \\
\hline
\end{tabular}

\subsection{Initial and boundary conditions}

The initial conditions are different for the model of the first and last closed cell. For the first closed cell no data were available of its interior. We used an initial temperature of $19{ }^{\circ} \mathrm{C}$, which was measured at the drain. For the initial liquid pressure we tried various configurations. We used a liquid pressure decreasing linearly from $0.1 \mathrm{MPa}$ at the phreatic level to $-0.9 \mathrm{MPa}$ at the base of the cell. This initial condition was used because it gave better fits for the leakage rate. For the last closed cell, a constant temperature of $16.5^{\circ} \mathrm{C}$ was used for the whole domain. Different initial liquid pressures were used according to the data measured by the sensors inside this cell. We consider a constant initial value of liquid pressure of -6.9 $\mathrm{MPa}$ for the wall, the roof and the concrete of the base of the cell. A value of $-49.9 \mathrm{MPa}$ was used for the container and $-99.9 \mathrm{MPa}$ for the gravel and porous concrete. 
For the subjacent rock, we use the same initial liquid pressure as the first closed cell, which has a value of $0.1 \mathrm{MPa}$ at the water table decreasing to $-0.9 \mathrm{MPa}$ at the base of the cell. The initial gas pressure is $0.1 \mathrm{MPa}$ for all models. Table 2 shows the boundary conditions that have been used. The temperature was prescribed and varies with time at the wall and roof of the cell, using the daily average temperature measured by the sensors situated outside the cell (Figure 3). These temperatures were used for the model of both the first and last closed cell. The difference is that the first starts at the summer of 2007 when data became available and the last starts about a year later, when the cell was closed. A leakage boundary condition was applied to the gap of air between the wall and the container allowing water to leave the cell only when liquid pressure exceeds atmospheric pressure. This represents the leakage to the drain. Finally, at the bottom of the model the water table was simulated by prescribing the liquid pressure to $0.1 \mathrm{MPa}$.

Table 2: Boundary condition applied in the numerical model

\begin{tabular}{llll}
\hline & Water & Heat \\
\hline Air gap & $q_{1}=\gamma_{1}\left(P_{\mathrm{g}}-P_{\mathrm{l}}\right) \quad$ if $\quad P_{\mathrm{l}} \geq P_{\mathrm{g}}$ & $j_{\mathrm{E}}=q_{\mathrm{l}} E_{\mathrm{l}}(T)$ & \\
& $q_{\mathrm{l}}=0 \quad$ if $\quad P_{\mathrm{l}}<P_{\mathrm{g}}$ & \\
Wall/roof & $q_{\mathrm{l}}=0$ & $T=T_{\mathrm{atm}}(t)$ & \\
Water table & $P_{\mathrm{l}}=P_{\mathrm{atm}}$ & $j_{\mathrm{E}}=q_{\mathrm{l}} E_{\mathrm{l}}(T) \quad$ if $q_{\mathrm{l}}>0$ \\
& & $j_{E}=q_{1} E_{1}\left(T^{\mathrm{ext}}\right) \quad$ if $\quad q_{1}<0$ \\
\hline
\end{tabular}

Where $q_{1}$ is the leakage rate of condensed water, $\gamma_{1}$ is the boundary liquid exchange coefficient $\left(\mathrm{kg} \mathrm{s}^{-1} \mathrm{~m}^{-2} \mathrm{MPa}^{-1}\right), T$ is the temperature $\left({ }^{\circ} \mathrm{C}\right)$ and subscript atm means atmospheric and superscript ext means external.

\section{Results and discussion}

\subsection{The first closed cell}

Figure 6 displays the results obtained for the numerical model of the cell that was closed first. Figure 6a shows the evolution of temperature calculated by the model, taking into account the external temperature of the west wall 
(Figure 3). The others are similar (not shown). Two periods every year can be distinguished: summer where the temperature is around $30^{\circ} \mathrm{C}$ and winter where the temperature is around $10^{\circ} \mathrm{C}$. The temperature of the wall has a larger amplitude than that of the container, which means that the wall is hotter than the container in summer and colder in winter, causing a temperature difference of approximately $3^{\circ} \mathrm{C}$. This gradient of temperature allows vapour to diffuse from the wall of the cell to the wall of containers through the air gap in summer, and the opposite in winter.

Temperature inside the cell is displayed at Figure $6 \mathrm{~b}$. The model results are the average of the temperature calculated by the 4 axisimetric models. Each model takes into account the external temperature of one wall of the cell. As shown, temperature at the drain oscillates between 19 and $22^{\circ} \mathrm{C}$. The model reproduces this variation with a similar amplitude but some retardation can be observed with respect to the measurements. The reason for this retardation is probably due to uncertainties with respect to the location of the sensor in the drain. Moreover, the thermal conductivity of the porous concrete, gravel and the rock were not calibrated, which may have some influence. Also, the gallery (filled with air) was not taken into account by the model, which could have an effect on temperature oscillations.

Figure $6 \mathrm{c}$ shows the relative humidity calculated by the model of the wall and the container, at both sides of the air gap at $3.5 \mathrm{~m}$ above the base of the cell. These results are from the model that takes into account the external temperature at the west wall. The others walls are similar (not shown). Two periods every year can be distinguished: summer and winter. In summer, the wall has a lower relative humidity, around $90 \%$, because of the evaporation taking place, whereas the container reaches $100 \%$ because of water condensation. The reverse occurs in winter, the container is dryer and the wall of the cell is saturated. According to equation 5 a temperature difference of $3^{\circ} \mathrm{C}$ gives a pressure suction of $25 \mathrm{MPa}$, which according to equation 2 corresponds to a relative humidity of $83 \%$. The model reaches a minimum of only about $90 \%$, which means that the extreme case of a completely dried up hot side is never reached.

Vapour pressure calculated by the model is shown in Figure 6d. Similarly to the relative humidity and temperature, summer and winter are distinguished. For both the wall and the containers vapour pressure is higher during summer than winter, because hot air can contain more vapour than cold air. The wall has slightly higher vapour pressure than the containers in summer and lower in winter. This small difference is the cause of evaporation 
at the hot and condensation at the cold side. Notice, that although vapour pressure is similar for the wall and the container, relative humidity always differs significantly, which is due to the temperature difference across the air gap.

The flow rate is displayed in Figure 6e. Model results are the average of the 4 axisymmetric models. Again the two periods (summer and winter) can be distinguished. Water from the water table enters to the cell; with a maximum of $5 \mathrm{l} / \mathrm{d}$ during the summer, because then the wall of the cell is dryer and larger amount of water can ascend from the water table. Condensed water leaves the cell also in two periods with large fluxes in winter (around $15 \mathrm{l} / \mathrm{d}$ ) and small fluxes in summer (less than $5 \mathrm{l} / \mathrm{d}$ ). Data are only available for the two last years, which the model reproduces well. From equation 3 we can calculate a maximum that can condensate in an extreme situation. Considering complete saturation and a temperature difference of $3^{\circ} \mathrm{C}$ we obtain a leakage rate of $111 \mathrm{l} / \mathrm{d}$. Obviously, in our case, we are far from this situation because lower values have been measured.

\subsection{The last closed cell}

First, we considered the same conceptual model as used for the first closed cell. This could reproduce reasonably well the data measured by the sensors situated at both sides of the air gap (sensors HP_07 and HP_12, respectively). However, it could not reproduce the relative humidity measured by the sensors inside the cell (HC_09, HC_10, HC_11). We obtained a constant value of relative humidity of about $70 \%$ without any oscillation as measured by the sensor (Figure 4). We conjectured that inside the gravel convection takes place due to the temperature gradient. Hence, we made a 2D model of the N-S section of the cell, taking into account gas flow inside the gravel. Figure 7 shows the results of both models.

\section{Axisymmetric model}

The axisymmetric model attempts to predict the data from the sensors at the wall of the cell and at the container separated by the air gap (sensors $\mathrm{HP}_{-} 7$ and HP_12, respectively). It uses the same conceptual model as used for the first closed cell, except for the initial conditions as explained in section 4.4. Figure 7 a shows the results of the model together with the data measured by the sensors. The model roughly reproduces the temperatures measured by the sensor. Nevertheless, it overestimates the temperature 
a)

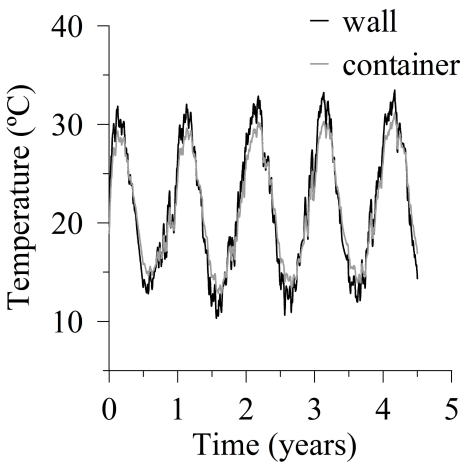

c)

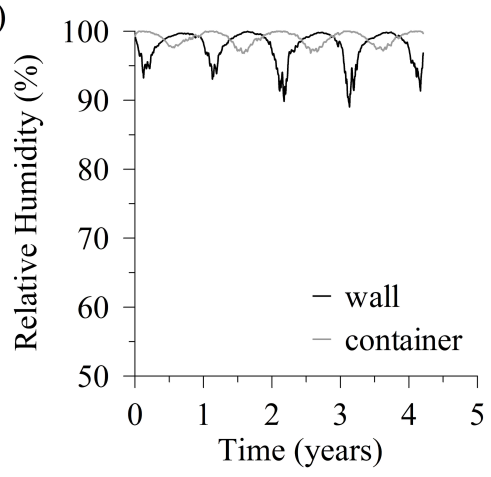

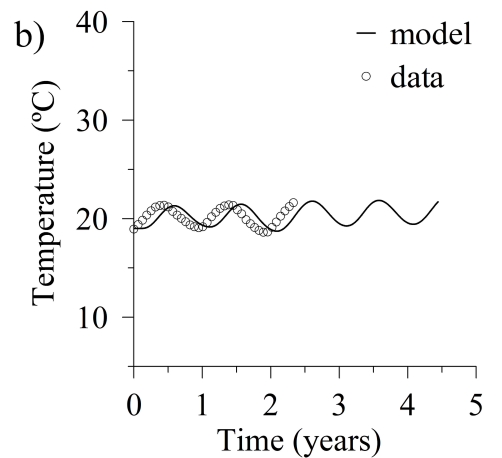

d)

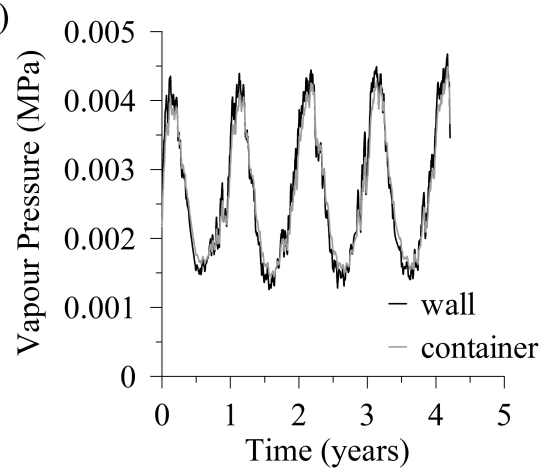

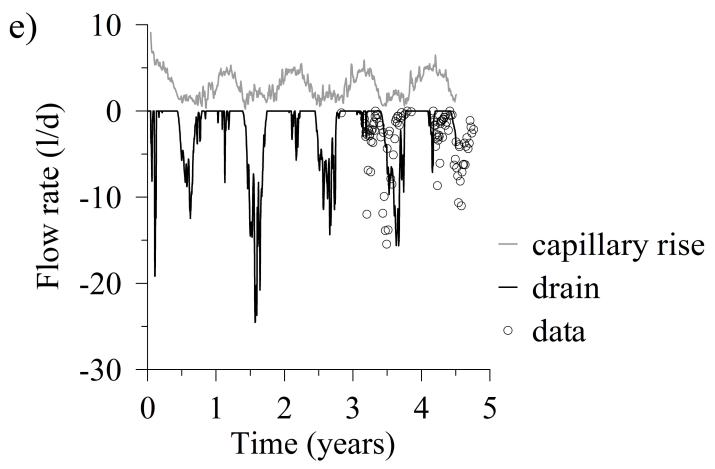

Figure 6: Results of the model of the first closed cell. a) Evolution of the calculated temperature of wall and container. The black line means wall and grey line means container, both separated by the $2 \mathrm{~cm}$ of the air gap at $3.5 \mathrm{~m}$ above the base of the cell. b) Evolution of temperature inside the drain. Points represent the data measured by the sensor located in the drain and the line presents the temperature calculated by the model. c) Evolution of relative humidity calculated by the model. d) Evolution of vapour pressure calculated by the model. e) Flow rate of water. Positive values mean that water enters the cell, and negative values mean that water leaves the cell. Calculated leakage rate of condensed water (lines) is compared with measured data (points). 
difference between the wall and the containers. This could be due the boundary conditions, which use temperatures for the first closed cell that may be somewhat different from that of the last closed cell. The model predicts a relative humidity similar to that of the first closed cell with high values at the containers and low values at the wall in summer and the reverse in winter. However, contrary to the first closed cell, the overall relative humidity is lower and never reaches $100 \%$ due to the drier initial conditions. Therefore, neither is there any leakage from the drain. Comparing the simulated with the measured relative humidity, we can see that the measured relative humidity shows much less difference between the wall and the containers, although both model and measurements show a higher relative humidity at the wall during winter and at the containers during summer. More importantly, during summer the measured values are much lower than the modelled results. This is also reflected by the vapour pressure, which is overestimated by the model during summer. These discrepancies can be explained partly by the size of the sensors discussed in section 3.2. However, it cannot explain the low relative humidity measured during the summer. We considered various scenarios to explain these measured values, such as, changing the initial values, the thermal conductivity, permeability and retention curve of the rock and concrete, but none of them resulted in better fits. A possible explanation is that the sensors are located close to the gravel, which may be effected by convection processes, as will be discussed in the next section.

\section{Model with convection}

A 2D model of the N-S section of the cell was made. This takes into account the walls of the cell (north and south) and the gravel inside the cell. Convection only takes place in the pores of the gravel, not in concrete, because the last is almost fully saturated and has a low permeability. The convection causes the circulation of gas, heat and vapour due to the gradient of temperature between the top of the cell and its base, and also between the wall and the centre of cell. As this phenomenon only takes place in the gravel, we compare the results of the model with the measurements of the sensors that are attached to the containers next to the gravel (sensors HC_09, HC_10, HC_11). Figure 8 shows the modelled fluxes of gas in summer. As can be seen the hot wall and roof causes a circular flow with gas rising near the wall and descending at the centre of the cell. This flow pattern is reversed in winter.

Figure 7 compares the evolution of temperature, relative humidity and 
vapour pressure calculated by the model with the ones measured by sensors. Temperature calculated has some retardation and less oscillation than the one measured by the sensors (Figure $7 \mathrm{~b}$ ). The model reproduces the relative humidity measured by the sensor qualitatively. It overestimates the relative humidity in summer and underestimates it in winter. The vapour pressure calculated by the model also overestimates the relative humidity in summer and underestimates it in winter with less oscillation, as they are a function of relative humidity and temperature (Eq. 2). These discrepancies are probably due to the fact that the model is a vertical $2 \mathrm{D}$ cross section and does not consider the third dimension. A 3D model would be necessary in order to better simulate the processes that take place into the cell. However, it would require a larger number of nodes, and CPU times would become excessive. Nevertheless, the model shows that oscillations of vapour pressure and relative humidity can be increased, curiously, by enhancing mixing gas through convection.

\section{Methods to avoid the phenomenon}

We propose three scenarios to avoid or remediate the phenomenon that causes water to leave the cell. Figure 9 shows the evolution of temperature and leakage rate for the three scenarios calculated by the numerical models. We simulated them with an axisimetric numerical model of the first closed cell during 10 years. We used the same boundary temperature condition as the first closed cell (Figure 3) for the first 4 years, which was repeated until the end (10 years).

The first scenario (Figure 9a) considers sand between the wall and the containers (instead of air). In this case the heat conduction gains importance, so that the difference of temperature between the wall and the containers is considerably reduced. The model shows seasonal oscillations of temperature from 30 to $10^{\circ} \mathrm{C}$, but the temperature difference between the wall of the cell and the container is negligible. Consequently, there is no leakage. However, water enters the cell at the phreatic level in summer (around $5 \mathrm{l} / \mathrm{d}$ ), and leaves it in winter (around $1 \mathrm{l} / \mathrm{d}$ ), thus, slowly saturating the cell. Obviously, if a saturation of 1 was reached, leakage in the drain would be reactivated avoiding accumulation of water inside the cell. We feel that the risk of radioactive waste contaminating the groundwater is low, because the amount of incoming water is larger that the outgoing one. 
a) axisymmetric model
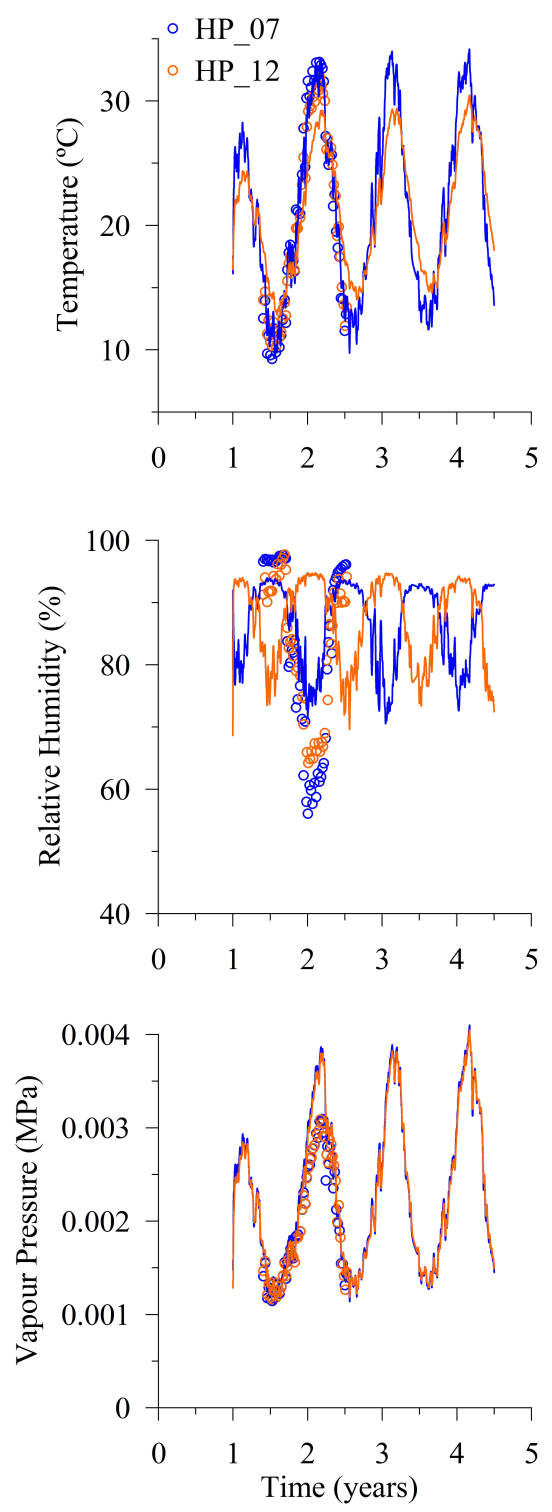

b) model with convection
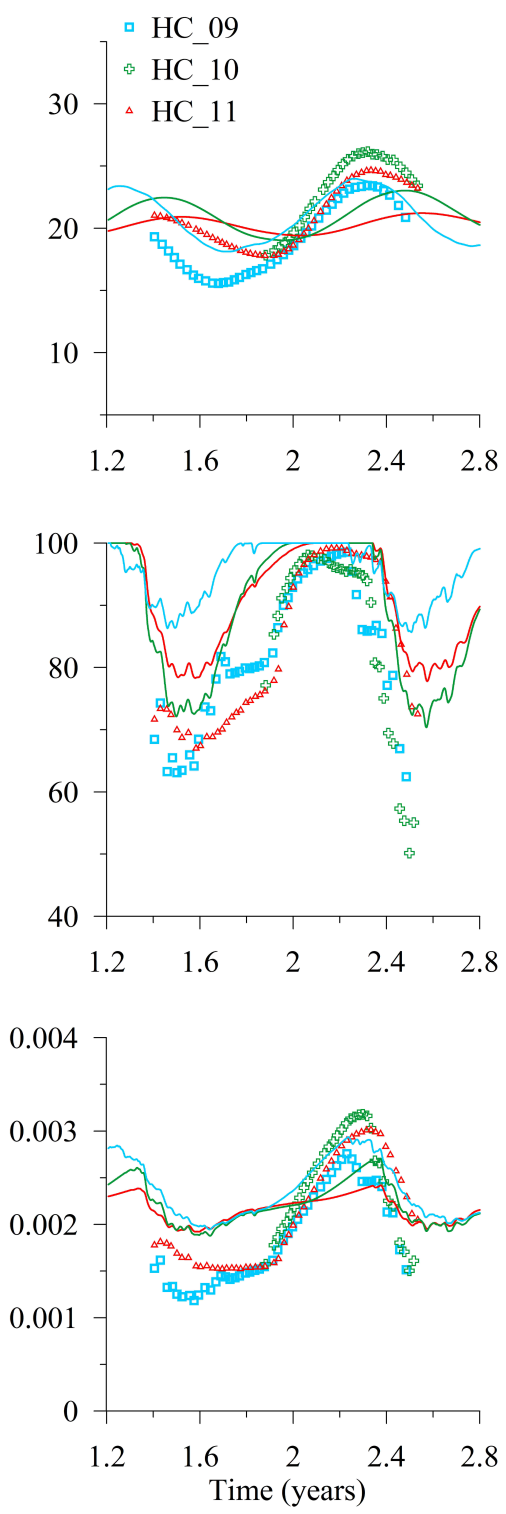

Figure 7: Evolution of temperature, relative humidity and vapour pressure calculated by the axisymmetric model and the model taking into account convection (lines) and measured by the sensors (points). 


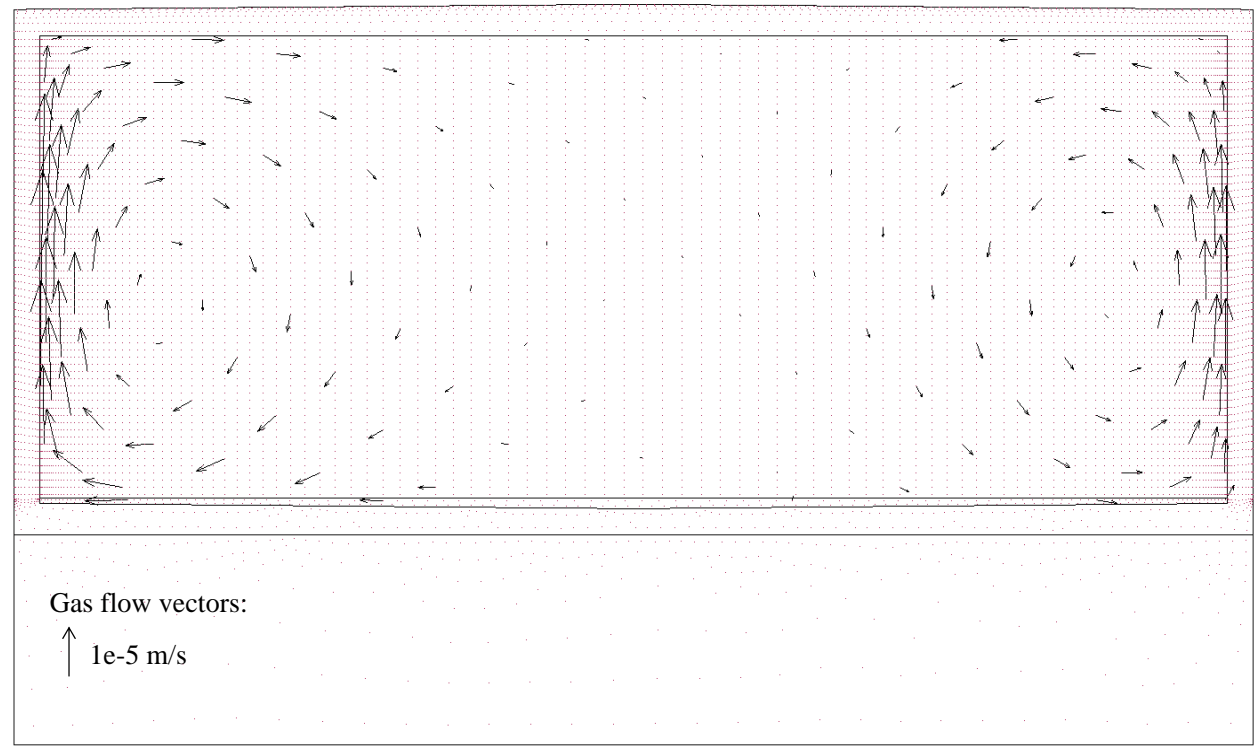

Figure 8: Geometry and results of the model with convection, situation in summer. Vectors of gas flow show the convection in the cells.

The second case (Figure 9b) considers a cover on top of the cell. The cover can reduce the oscillation of temperature and the gradient of temperature between the wall of the cell and the container. To do so, the boundary condition of temperature was changed. We prescribed the temperature varying with time, on the wall and the roof of the cell, taking into account the thickness of the cover. Results show that the oscillation of temperature decreases considerably, to a maximum of $23^{\circ} \mathrm{C}$ and a minimum of $19^{\circ} \mathrm{C}$. In this case, the difference of temperature between the wall of the cell and the wall of containers is very small, less than $0.5^{\circ} \mathrm{C}$. Water does not leave the cell from the air gap between the wall of the cell and the containers. Water is always entering the cell at the water table, at a rate of 1 to $2 \mathrm{l} / \mathrm{d}$. Probably this will continue until a hydrostatic situation is reached at the cell.

The third scenario (Figure 9c) considers a capillary barrier. It consists of $0.5 \mathrm{~m}$ of gravel, situated between the base of the cell and the underlying rock. The model shows seasonal oscillations of temperature, and also a gradient of $3^{\circ} \mathrm{C}$ between the wall of the cell and the containers. Water vapour can diffuse through the capillary barrier due to oscillation of temperature outside the cell, by means of the same mechanism as at the air gap (around $1 \mathrm{l} / \mathrm{d}$ ). 
This means that water can still enter or leave the cell, although at rates lower than without the capillary barrier (See figure 9d). Also water is still collected at the drain, but with lower rates. In the first two years $10 \mathrm{l} / \mathrm{d}$ of water is collected because of the initial condition. From then on, the rate drops to around $1 \mathrm{l} / \mathrm{d}$ with some peaks between 6 and $8 \mathrm{l} / \mathrm{d}$.

The forth case (Figure 9d) not only considers a multilayer cover, but also a capillary barrier. Results show that temperature of the wall of the cell and the container is equal and pretty much constant (around $21^{\circ} \mathrm{C}$ ). Neither water is collected at the drain, nor water enters the cell at the phreatic level.

\section{Conclusions}

The model of the cell that was closed first confirms that water drains from the cells due to evaporation and condensation processes inside concrete:

- There is a gradient of temperature between the wall of the cell and the wall of the containers, which causes vapour diffusion through the air gap. The temperature inside the drain agrees well with that measured by the sensor.

- Relative humidity calculated by the model shows that in summer the wall is drier (due to evaporation) and the container is saturated (due to condensation). In winter it is the opposite.

- The model shows that water enters the cell at the phreatic level and leaves it at the drain. There is a good agreement between the modelled and measured leakage rates.

It must be said, though, that this model has only been calibrated by measurements at the drain in the centre of the cell. So, it may not be able to confirm more details on the processes. In the last closed cell sensors for temperature and relative humidity were installed, which permits the study of these processes at more detail. The model of this last closed cell, with the same assumptions as that of the first closed cell, shows some discrepancies with the measured data. Measured vapour pressure near the air gap are lower than those predicted by the model. This could indicate air instabilities due

to temperature differences. Also the model cannot reproduce oscillations of relative humidity, measured inside the cell. However, a model that simulated flow of gas through the gravel shows that these oscillations can be caused by convection. 
a) with sand
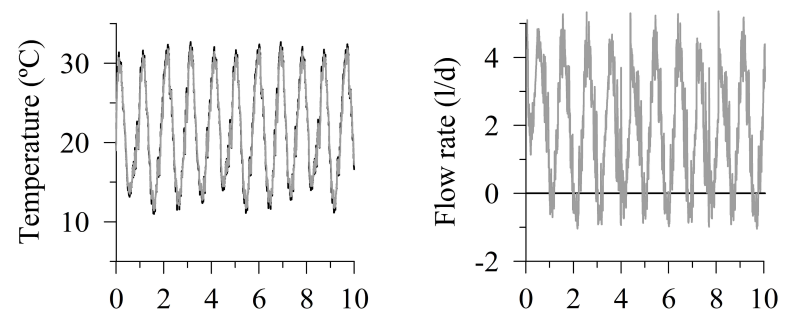

b) with cover
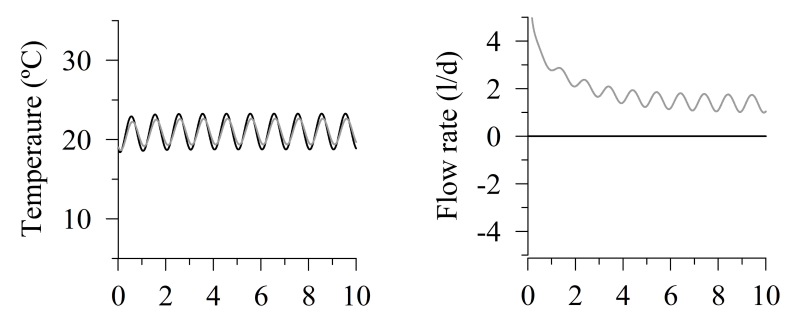

c) with barrier
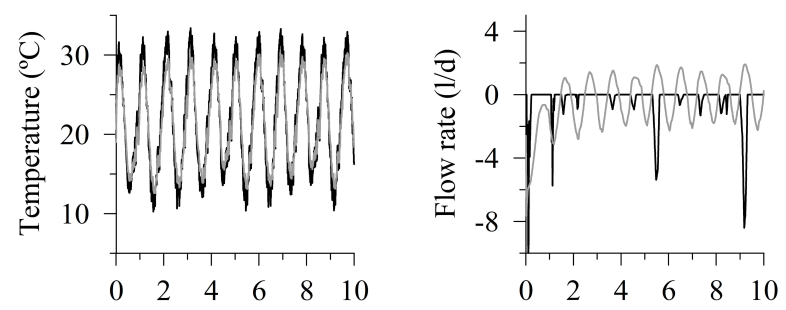

d) with cover and barrier
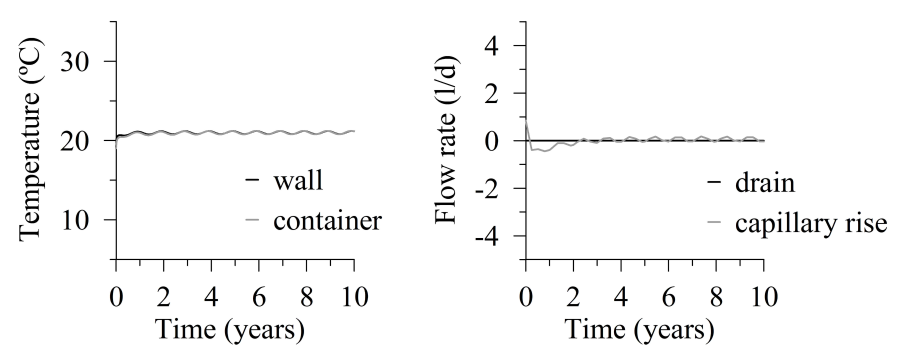

Figure 9: Evolution of the calculated temperature and flow rate for the model with sand between the wall and container, with a cover, with a barrier and with a barrier and cover. 
The numerical models suggest that the design of this kind of structures should take into account: temperature gradients, vapour diffusion inside the cells through air gaps, capillary rise from the phreatic level and possibly gas flow through air gaps and gravel.

The temperature gradients can be avoided filling the air gap with sand or they can be highly reduced with a cover. Using a cover and a capillary barrier the flux from the phreatic level could be considerably reduced. In all of these cases no water is collected at the drain. Using only a capillary barrier the rate of leakage to the drain is considerably reduced, although not eliminated.

\section{Acknowledgements}

This work was funded by ENRESA (Spanish Nuclear Waste Management Company) and a Research Grant from the Technical University of Catalonia (UPC).

\section{References}

Andrade, C., Sarra, J., Alonso, C., 1999. Relative humidity in the interior of concrete exposed to natural and artificial weathering. Cement and Concrete Research 29, 1249 - 1259.

Banimahd, S., Zand-Parsa, S., 2013. Simulation of evaporation, coupled liquid water, water vapor and heat transport through the soil medium. Agricultural Water Management 130, 168 - 177.

Bažant, Z., Najjar, L., 1972. Nonlinear water diffusion in nonsaturated concrete. Matériaux et Constructions 5, 3-20.

Bittelli, M., Ventura, F., Campbell, G. S., Snyder, R. L., Gallegati, F., Pisa, P. R., 2008. Coupling of heat, water vapor, and liquid water fluxes to compute evaporation in bare soils. Journal of Hydrology 362, 191 - 205.

Chaparro, M. C., Saaltink, M. W., Villar, M. V., 2015. Characterization of concrete by calibrating thermo-hydraulic multiphase flow models. Transport in Porous Media 109, 147-167. 
Gawin, D., Baggio, P., Schrefler, B., 1995. Coupled heat, water and gas flow in deformable porous media. International Journal for Numerical Methods in Fluids 20, 969-987.

Gran-Esforzado, M., 2015. Coupled heat and water flow dynamics in dry soils. application to a multilayer waste cover. Ph.D. thesis, Universitat Politècnica de Catalunya (UPC).

Grifoll, J., Gast, J. M., Cohen, Y., 2005. Non-isothermal soil water transport and evaporation. Advances in Water Resources 28, 1254 - 1266.

Häupl, P., Grunewald, J., Fechner, H., Stopp, H., 1997. Coupled heat air and moisture transfer in building structures. International Journal of Heat and Mass Transfer 40, $1633-1642$.

Liu, J., Aizawa, H., Yoshino, H., 2004. CFD prediction of surface condensation on walls and its experimental validation. Building and Environment $39,905-911$.

Lü, X., 2002. Modelling of heat and moisture transfer in buildings: I. model program. Energy and Buildings 34, 1033 - 1043.

Massana, J., Saaltink, M. W., 2006. Modelo 2D de la celda 16, report. Tech. rep., Dept. Geotechnical Engineering and Geosciences, Universitat Politècnica de Catalunya.

Olivella, S., Carrera, J., Gens, A., Alonso, E., 1996a. Porosity variations in saline media caused by temperature gradients coupled to multiphase flow and dissolution/precipitation. Transport in Porous Media 25 (1), 1-25.

Olivella, S., Carrera, J., Gens, A., Alonso, E. E., 1994. Non-isotermal multiphase flow of brine and gas through saline media. Transport in Porous Media 15, 271-293.

Olivella, S., Gens, A., Carrera, J., Alonso, E. E., 1996b. Numerical formulation for a simulator (code_bright) for the coupled analysis of saline media. Engineering Computations 13 (7), 87-112.

Philip, J. R., De Vries, D. A., 1957. Moisture movement in porous materials under temperature gradients. Eos, Transactions American Geophysical Union 38, 222-232. 
Sakai, M., Toride, N., Šimůnek, J., 2009. Water and vapor movement with condensation and evaporation in a sandy column. Soil Science Society of America Journal 73, 707-717.

Villar, M., Martín, P., Barcala, J., 2009. Caracterización del material de cobertera y el hormigón del c.a. el cabril. Tech. rep., CIEMAT.

Zuloaga, P., Andrade, C., Saaltink, M. W., 2006. Long term water flow scenario in low-level waste disposal vaults, with particular regard to concrete structures en el cabril, cordoba, spain. J.Phys IV, France 136, 49-59. 